УДК 621.74

\title{
M. P. Романиunur
}

\section{MIKPOCTPУKTYPA ПОВEPXHEВИХ IIAPIB HOWIB 3I CTAЛI 6XC}

Наведені результати мікроструктурного аналізу поверхневих шарів деревообробних ножів після експлуатації протягом дев'яти місящів зі сталі 6ХС. Запропоновані можливі варіанти відновлення та покращення різальних властивостей виробів.

Ключові слова: деревообробні ножі, поверхневі шари, мікроструктура, сталь 6ХС.

\section{1. Встул}

Проведені дослідження належать до галузі матеріалознавства. Інструментальні матеріали є одними із найбільш вживаних матеріалів для виготовлення інструменту для будь-якої сфери виробництва. Це стосується як стабільності мікроструктури ріжучої поверхні, так і забезпечення запасу довготривалої міцності ножів зі сталі 6ХС. Отже, дослідження, про яке йдеться в доповіді є актуальним та своєчасним.

\section{2. Лостановка проблеми}

Після виготовлення деревообробного інструменту виникають певні труднощі при термічній та хіміко-термічній обробці для забезпечення високих експлуатаційних властивостей. Для довготривалої та надійної роботи необхідна висока зносостійкість та міцність ріжучої поверхні виробу. Тому існує проблема розробки економічної, екологічно чистої поверхневої обробки для забезпечення необхідного комплексу властивостей інструменту.

\section{3. Осковна частина}

3.1. Аналіз літературних джерел по темі дослідження. У роботах $[1,2]$ наведена набута автором в процесі професійної діяльності інформація щодо властивостей та поведінки в різних робочих середовищах сталей та сплавів з особливими властивостями.

У працях [3-6] розглянуті способи відновлення поверхні, котрі проводять з метою підвищення експлуатаційних властивостей інструменту. Проаналізовано механізм структуроутворення спрацьованої поверхні виробу, оптимізовано технологічний процес відновлення інструменту методами інженерії поверхні.

3.2. Результати досліджень. Методом макрота мікроструктурного аналізу було виявлено численні пошкодження різальних кромок інструментів (рис. 1) внаслідок експлуатаційних процесів. До них належать виявлені у мікроструктурі дефекти, зокрема відколи, розташовані вздовж поверхні

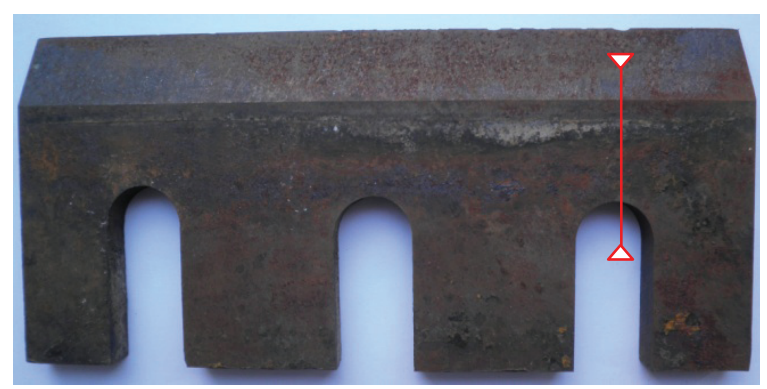

a

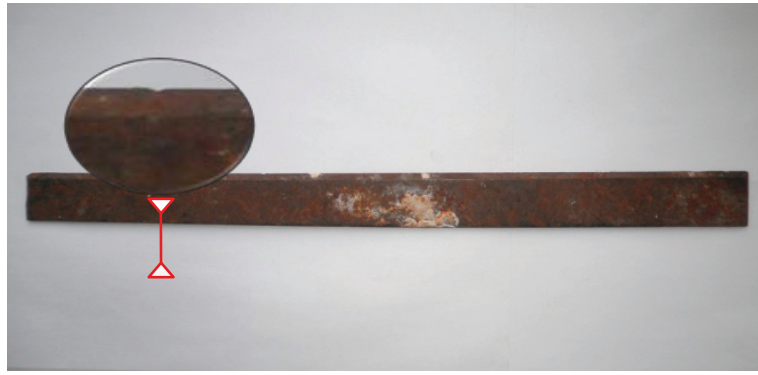

Pис. 1. Загальний виглнд деревообробних ножів (червоною лінією вказане місце вирізання зразків):

a - для різання шпону; б - з прнмолінійною кромкою для фрезерування (далі «ніж № 2»)

ріжучої кромки. В об’ємі ножа можна ідентифікувати пори та дрібні включення карбідів. На вістрі ріжучої кромки - незначне відшарування та корозійна тріщина (рис. 2).

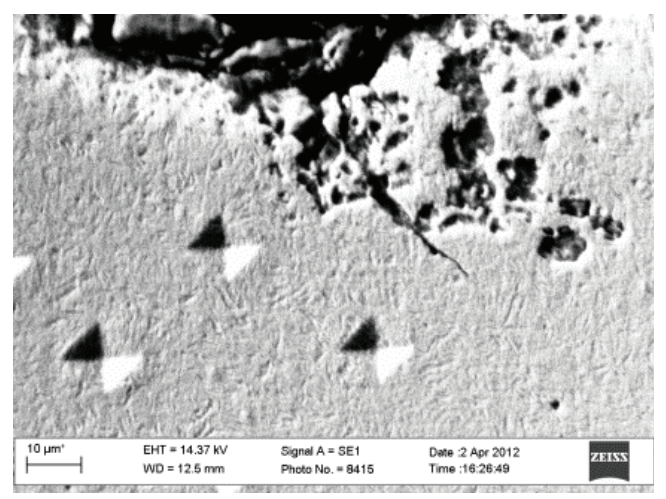

Pис. 2. Мікроструктура поверхні ріжучої кромки деревовбробного інструменту 
Негативний вплив дефектів на працездатність інструменту підтверджено результатами проведеного вимірювання мікротвердості.

Спектральним аналізом окрім заліза було виявлено великий відсотковий вміст хрому у сталі. Це дає підстави вважати за доцільне проведення іонного азотування поверхні зразків.

Отже, в процесі обробки деревообробних ножів методами інженерії поверхні очікується значне зростання їхніх експлуатаційних властивостей.

\section{Лiтература}

1. Дурягіна 3. А. Сплави з особливими властивостями. [Текст] / 3. А. Дурягіна, О. Я. Лизун, В. Т. Пілюшенко. - Львів : Національний університет «Львівська політехніка». - 2007. - 236 с.

2. Дурягіна 3. А. Фізика та хімія поверхні [Текст] : монографія / 3. А. Дурягіна. - Львів : Національний університет «Львівська політехніка». - 2009. - 208 с.

3. Дурягіна 3. А. Моделювання електронної будови мікрокристалічних поверхневих шарів, одержаних лазерним модифікуванням [Текст] / 3. А. Дурягіна, Н. І. Павленко, Н. В. Щербовських // Фізична інженерія поверхні. - 2008. - Т. 6. - № 3-4. - С. 160-163.

4. Дурягіна 3. А. Комп'ютерне моделювання оптимальних параметрів лазерного легування корозійнотривких сталей [Текст] / 3. А. Дурягіна, Г. В. Лазько, Н. В. Щербовських // Нові матеріали і технології в металургії та машинобудуванні. - 2008. - № 1. - С. 20-25.

5. Пашечко M. I. Самоорганізація поверхні при зношуванні та корозії [Текст] / М. I. Пашечко, 3. А. Дурягіна // Металознавство та обробка металів. - 2002. № 3. - C. 26-35.

6. Дурягіна 3. А. Функціональні поверхневі шари, створені лазерним легуванням [Текст] / 3. А. Дурягіна
// Вісн. Нац. ун-ту «Львівська політехніка». - Оптимізація виробничих поцесів і технічний контроль в машинобудуванні і приладобудуванні. - 2001. - № 422. С. $98-103$.

\section{МИКРОСТРУКТУРА ПОВЕРХНОСТНЫХ СЛОЕВ НОЖЕЙ ИЗ СТАЛИ 6ХС}

\section{P. Романишин}

Приведены результаты микроструктурного анализа поверхностных слоев деревообрабатывающих ножей после эксплуатации в течение девнти меснцев из стали 6ХС. Предложены возможные варианты восстановления и улучшения режущих свойств изделий.

Ключевые слова: деревообрабатывающие ножи, поверхностные слои, микроструктура, сталь 6ХС.

Михаил Ростиславович Романишин, магистр кафедры инженерного материаловедения Национального университета «Львовская политехника», тел.: (063) 3424127,

e-mail: remua@ukr.net.

\section{THE MICROSTRUCTURE OF SURFACE LAYERS OF GKHS STEEL KNIVES}

\section{Romanyshyn}

The work provides the results of surface layers microstructural analysis of 6KHS steel woodworking knives after nine months in service. The survey puts forward the perspectives for further restoring and improving the cutting properties of the instruments.

Keywords: woodworking knives, surface layers, microstructure, steel 6KHS.

Michael Romanyshyn, graduating student of Department of applied Material Science, National University «Lviv Polytechnic», tel.: (063) 3424127, e-mail: remua@ukr.net. 